\title{
Gyula Horváth
}

Centre for Regional Studies, Hungarian Academy of Sciences; H-7621 Pécs,

Papnövelde u. 22, Hungary; Tel.: +36 72523 801; Fax: +36 72523 803;

e-mail: horvath@rkk.hu

\section{고 REGIONALIZATION IN EASTERN AND CENTRAL EUROPE: OBSTACLES AND PERSPECTIVES}

\begin{abstract}
Regional policy depends on efficient administrative systems for designing and implementing strategies, and places considerable demands on Member States' public administrations in terms of e.g. financial management and monitoring; project selection procedures; ex ante environmental impact assessments and costbenefit analyses; and the monitoring and evaluation of outputs, results and impacts. EU member states have taken a range of different approaches to the administration of regional policy.
\end{abstract}

The construction of regions in the countries of Eastern and Central Europe became one of the important debate topics for preparation for EU membership. Despite the numerous similarities in the changes that have taken place in the territorial structures of the Eastern and Central European countries, the differences in the responses individual countries gave to the challenges of regional development and the varied results of their development efforts demonstrate that the "Eastern European Bloc" is at least as heterogeneous as the former member states of the European Union. EU accession opened up a Pandora's Box in the countries of Eastern and Central Europe. The fundamental issue of how unitarily structured states can be set on a decentralised path became the centre of debate. The paper introduces the Central and Eastern European achievements of region building processes and searches for an explanation of the reasons for the difficulties of Eastern and Central Europe in regional construction; it summarises the administrative and political development pre-requisites of the transition to a regional outline of the possible advantages of a regional institutional system in the creation of the Cohesion Policy ensuring a decrease in regional differences.

KEY WORDS: regionalism, regional development, structural and cohesion policy, Eastern and Central Europe, European Union

\section{INTRODUCTION}

Regionalism, the regional decentralisation of power and the distribution of labour among the different forms of local government have found themselves in the crossfire of debate in the unitary states of Eastern and Central Europe [Enyedi, Tózsa, 2004; Horváth, 2010; Keating, Hughes, 2003; Lütgenau, 2011]. The change of the political system, the process of connecting to the globalising European economy, the construction of a local governmental structure using the concepts of civic democracy, all shed new light on the mutual connections of central and regional local power, the harmonisation of settlement independence and meso-level public administration functions. In almost all of the former socialist countries the central issue became that of the economic, political and functional transformation of the basic levels of local government. The earlier sub-national levels disappeared (as in the successor states of the old Czechoslovakia), their functions to a large extent decreased (as in Hungary), changed (as in Poland), or, 
alternatively, new regional meso-levels were created (as in Croatia) or are being created (as in Slovenia).

The construction of regions in the countries of Eastern and Central Europe became one of the important debate topics for preparation for EU membership [Bachtler, Downes, Gorzelak, 2000; Michalski, Saraceno, 2000]. However, the application of EU structural policy relates to appropriate size in terms of the population potential of sub-national development units and their economic capacities, in view of the concepts of economies of scale, and so, during the preparation of the EU pre-accession programmes, planning-statistical regions had to be created in all countries. From a formal point of view, solving this task did not create any particular problem. The government of each country listed the regional public administration units as meso-level development regions, and, on the basis of EU recommendations, the formal organisational structures (regional development councils, development directorates and agencies) were also created.

In parallel with the creation of the organisational framework of an EUcompatible development policy, there started, in most countries, an intensive debate on issues of content. In these debates, numerous issues (which had earlier received less attention among the topics relating to the change of regime) were raised: What functions should the development regions have? How can they become public administration units serving the decentralisation of the centralised state system? What resources should they have to fulfil the development programmes? Which city in the region should become the regional centre?

EU accession opened up a Pandora's Box in the countries of Eastern and Central Europe. The fundamental issue of how unitarily structured states can be set on a decentralised path became the centre of debate. This present study searches for an explanation of the reasons for the difficulties of Eastern and Central Europe in regional construction; it summarises the administrative and political development pre-requisites of the transition to a regional outline of the possible advantages of a regional institutional system in the creation of the Cohesion Policy ensuring a decrease in regional differences.

\section{THE FORMAL CHANGE IN REGIONAL ADMINISTRATION}

The new nation-states in Eastern and Central Europe established in the aftermath of World War I had to face - from the point of view of their future regional development - two difficulties. One of the issues to be addressed was how to create a unified structure for those (new) parts of the country which earlier had been developed in different economic areas, in order to link their infrastructural systems. The other was to create a new system of regional organisation of central government power. The heavily centralised state powers created their own regional bodies partly on their former administration basis, but completing those tasks needed to create the new, unified state territory was most effectively assisted by the low number of administrative units involved. Following World War II, the Soviet-style regional administration was organised differently - now based upon different power considerations. The Communist states, in accordance with their political interests, heavily changed the countries' regional administration on several occasions, sometimes organising smaller regional units and sometimes larger. Hungary can be considered as an exception to this, in that, in the $20^{\text {th }}$ century (apart from some under-populated counties being combined) the number of sub-national units in the country has not changed (Table 1).

In Eastern and Central Europe a hierarchical planning organisational system - with a fairly powerful central planning office at the top in each country - had previously been the decisive organisational form of regional development. Regional development based 
Table 1. Changes in the number of regional administrative units

in Eastern and Central European countries

\begin{tabular}{|c|c|c|c|c|c|c|}
\hline Country & Pre-WW II & $1950 s$ & $1960 \mathrm{~s}$ & 1970s & $1980 \mathrm{~s}$ & 2009 \\
\hline Bulgaria & 9 & 13 & 28 & 28 & 9 & $28^{1999}$ \\
\hline $\begin{array}{l}\text { Czech Re- } \\
\text { public }\end{array}$ & 2 & 13 & 8 & 8 & 8 & $14^{2001}$ \\
\hline Hungary & 25 & 20 & 20 & 20 & 20 & 20 \\
\hline Poland & 14 & 22 & 22 & 49 & 49 & $16^{1999}$ \\
\hline Romania & 9 & 18 & 18 & 40 & 41 & 42 \\
\hline Slovakia & 2 & 6 & 4 & 4 & 4 & $8^{1996}$ \\
\hline
\end{tabular}

Source: The author's own design.

on central large-scale investment and state social policy did not require a multiparticipant institutional system operating in horizontal co-operation, and the state's interest in re-distribution, together with the central will, were carried out most effectively by vertically subordinated organisations. This philosophy of state organisation also defined the regional administration system.

Following the change of regime, the organisational framework of Eastern and Central European states underwent important conceptual changes [Blažek, Boeckhout, 2000; Boev, 2002; Gorzelak, 1998; Horváth, 1996; Illner, 2000; Stasiak, 1999]. A local government structure has replaced the hierarchical, executive council system, and the related legislation has created the constitutional basis for a decentralised exercise of power. By now, in fact, local authorities have been equipped with constitutional guarantees of their organisational and decisionmaking independence, and very significant changes have been introduced into local government financing. In formal terms, public administration in Romania and Hungary has remained unchanged, although in Bulgaria the previous multicounty system was restored. At the same time, both the Czech Republic and Slovakia (as in the period between 1949 and 1960) created counties relatively small in size. Only Poland established large-size "voivod-ships" and here the reform of the country's public administration has been an important milestone in the process of preparing for EU accession.

It is, therefore, quite evident that the question of the public administration units (meso-level) positioned between central government and the settlements will continue to be an open issue - and extremely important from the point of view of regional policy. It is, in fact, a general phenomenon in Eastern and Central Europe that these levels - as a reaction to the negative role which they mainly played under the previous system and their extremely strong political and redistributive functions - have very few local administration rights.

\section{THE DEVELOPMENT AND STATISTICAL REGIONS}

A pre-requisite for Eastern and Central European countries to join the EU or to benefit from support from the Structural Funds was the creation of large regions (NUTS 2 units): on this basis the most effective development concepts, and the programmes serving their realisation, could best be drawn up. The 206 NUTS 2 regions established in the 15 member states of the EU are very different from the point of view of their public law and administration situation and their physical size and population numbers. Basically, we are looking at units nationally determined, in which, at the same time as the NUTS 2 system of each country 
should meet common requirements, they operate as statistical (calculating, analysing, planning, programming, coordinating) and developing (support policy, decentralising) units. In the 10 Eastern and Central European member states the number of meso-level administration units at the end of 1999 was 357, and it was clear that the EU's support policy could not supervise such a high number of regional units. In consequence, it became essential to create larger regional development and statistical units.

Defining boundaries within the NUTS system is, from the EU's point of view, an internal affair - which means that, apart from size, there are no absolute EU requirements in terms of the creation of the regions: the decision lies within the scope of national governments. However, on the basis of experience with creating regions, the various concepts and likely impacts can be expressed in a way which makes the definition of the region relatively straightforward:

- a prehistory of regional cooperation and hence, the chances of regional cohesion,

- relative size status from the point of view of the national regional structure,

- relative spatial homogeneity in terms of the basic aims of regional policy,

- an effective internal structure (centre, subcentres, skills and the ability to cooperate etc) of a region and the observance of public administration borders,

- the existing (or demanded) "geopolitical" similarity of the units united in a region and the degree of identity of the definitive, long-term, international orientations,

- the costs of creating and operating the regions (decision-preparing, decisionmaking and professional administrative background institutions, organising the information, planning, managing and monitoring activities, the institutional system of decentralised financing etc), the economies of scale from a functional point of view,

- the existence of a multi-functional, major urban regional centre.

The NUTS 2 regions are listed in the Regional Development Acts or Government Decrees of each country. However, the Regional Development Act adopted in Hungary in 1996 was quite cautious, indicating merely that the counties could create regions in order to carry out common tasks. It did not, however, define the development regions of the country; and this imprecise regulation had, as a consequence, the fact that counties joined together widely differing regions purely for fund-raising purposes - and there were counties which participated in three or four regional alliances However, the Amendment to the Act in 1999 defined seven development statistical regions and separated the counties into regions. In fact, a Government Decree listing, in an itemised form, the theoretical concepts defining development regions was created only in Bulgaria [Geshev, 2001]. The Bulgarian Government defined the aspects of the creation of the regions in 1999 as follows:

- The number of regions should be relatively low and they should be defined on the basis of their size and natural resource potential; their economic and social capacities should be able to undertake large-scale programmes;

- The regions should not be too large to be manageable, and the number of counties comprising a region should be optimal in order to be able to organise their cooperation;

- There should be a common development problem in the region which could be felt in any point of the region and which motivates the regional development actors to cooperate; 


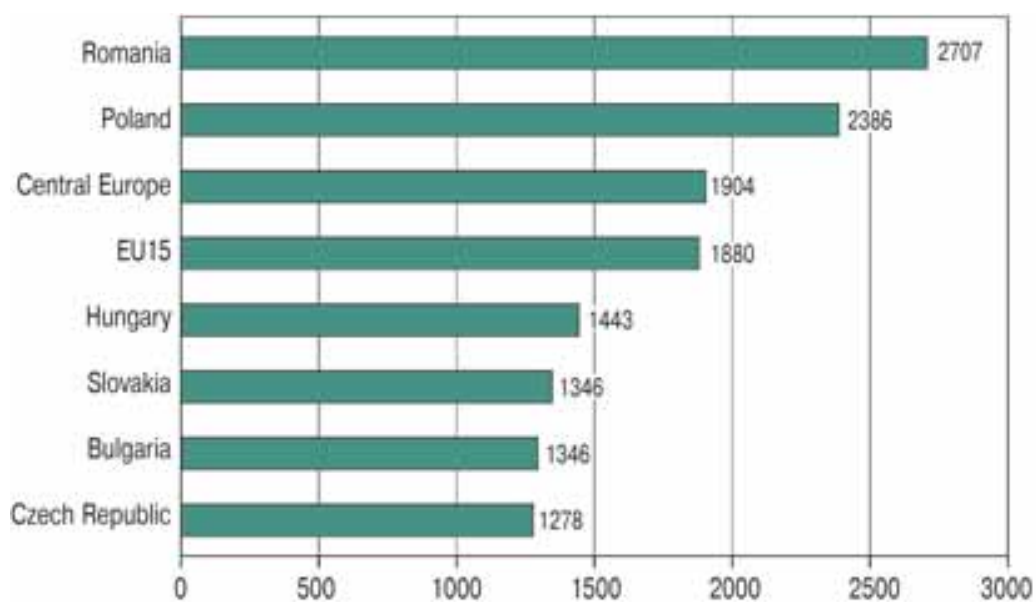

Fig. 1. Average population of NUTS 2 regions in Central Europe (2009, '000)

Source: The author's own calculations on the basis of Regions. Statistical Yearbook, 2006

- Natural geographical units and historical traditions should be taken into consideration;

- The region should have a relatively developed urban network and several growth-poles;

- The planning region should comprise complete public administration units.

In the other countries, and after long debate, a compromise decision was reached in terms of the creation of NUTS 2 regions, and these (more or less) matched the above basic concepts. As regards size, they parallel very closely the average of the earlier EU member states (Table 2, Fig. 1). Individual countries, however, did not come to define their central regions in the same way. In Bulgaria, Poland, Hungary and Romania, for example, the capitals, together with their surrounding "Metropolitan" regions, made up one NUTS 2 unit, whilst, in the Czech Republic and Slovakia, the capitals alone constitute one single region. Since there is also visible in Eastern and Central Europe that general pattern of spatial economy in which the larger region surrounding a country's most developed growth pole can

Table 2. The most significant data of NUTS 2 units in Eastern and Central Europe, 2009

\begin{tabular}{|l|c|c|c|}
\hline \multirow{2}{*}{ Country } & \multicolumn{3}{|c|}{ NUTS 2 regions } \\
\cline { 2 - 4 } & Number & $\begin{array}{c}\text { Average area } \\
\left.\text { ('000 } \mathbf{~ k m}^{2}\right)\end{array}$ & $\begin{array}{c}\text { Average population } \\
\text { ('000s) }\end{array}$ \\
\hline Bulgaria & 6 & 18.5 & 1,294 \\
Czech Republic & 8 & 9.9 & 1,278 \\
Hungary & 7 & 13.3 & 1,463 \\
Poland & 16 & 19.5 & 2,386 \\
Romania & 8 & 29.8 & 2,707 \\
Slovakia & 4 & 12.2 & 1,346 \\
ECE & 49 & 14.7 & 1,904 \\
EU15 & 206 & 15.3 & 1,880 \\
\hline
\end{tabular}

Source: The author's own calculations on the basis of Regions. Statistical Yearbook, 2006. 
show weaker performance (a consequence of the "filtering-down" effect), this solution generated strong debate in Hungary. The overall performance of the Central Hungary region (due to Budapest's high GDP per capita) is as much as 105\% of the average of the EU-27 and could not, therefore, be included in the Objective for convergence. Support, therefore, is more modest. (Budapest itself produces $144 \%$ of the EU average, whilst the region's remaining unit, Pest county, produced just 55\% in 2009). Similar problems can be noted in the other countries also.

\section{THE DILEMMA OF THE REGIONAL CENTRES}

Those larger towns or cities can be called regional centres which, on the basis of their size and geographical location, fulfil the role of administrative, industrial and transport centre of a large area which is home to between one and three million inhabitants. These stand out from their surroundings and enjoy a higher proportion of the resources of their region than would be justified by their population.

Due to the influence of urban development processes, the regional centres of Western Europe built up their position over centuries, and their functional accumulation of wealth and growth ofresourcesareclosely connected with their region. In their development, the restructuring of the economy and the quality change in their transport and service sectors also played a major role. The settling and gradual expansion of the leading positions of central and local government administration, naturally, played their part also, in that more favourable conditions were created in these cities to enable them to accept the new economic growth-driving forces - although, in the development of their performance capacity, administrative factors can only be seen as secondary resources. Their dynamism was basically generated by the role of industry and services affecting both their regional and their wider markets. It is, therefore, no accident that, when the institutionalisation of regionalism - in particular countries in different development phases - led to changes in public administration, the choice of headquarters for a region seemed quite obvious in each West European country: the largest city, the richest in functional terms, the most outstanding in economic potential became the centre of public administration for the region.

In many countries the decentralising trends of national regional policies, and especially the growth-pole concepts, played an important role in the development of the regional centres [Cities in the new EU countries, 2004; Potentials for polycentric development in Europe, 2004; Schindegger, Tatzberger, 2002; Waterhout, 2002]. The essence of the use of the growth-pole strategy was that those innovations given regional development support were directed only to a limited number of locations (mainly as a part of the planned concept targeting the modification of the regional spatial structure), attempting to support economic activity to raise the level of welfare within the region. The creation of the growth-pole was, first of all, motivated by complex industrial development, by the dominant new (or modernised) economic sectors and developed services. Using the principles of the French spatial economics school in economic policy resulted in an essential strengthening of connections in the economic space among companies and sectors.

Paralleling the clear results achieved in the development of those major urban centres which are treated as poles, the consequences in terms of the effect as experienced on regional transformation are less favourable. It is not in every country that growth-poles have been developed as the driving forces of regional development, and especially in those countries where the spatial-political, politico-economic and the political strategies involved in public administration could not be framed within a unified system, the results of the use of this paradigm are spoken of with some scepticism., The elaboration and fulfilment of their (incomplete) policies were 
not embedded in a unified decentralised concept, but appeared as separate, disjointed steps or attempts to reform, and they were ineffective - especially since the underperformance of the synergies produced some undesired results.

As a consequence of the multi-coloured administrative structure of European countries, we can speak of regional centres in a variety of ways. In countries with a federalised and regionalised system, the public administration centres work at the meso-level as real regional centres, whereas, in centralised, unitary countries the centres of the NUTS 2 units have more limited (planning and organising) functions.

In the development of regional centres in each country many identical and numerous specific factors played a role. However, the general trend seems clear, in that, in the great majority of European regions, the largest town or city is the centre of the region. However, as a result of European urbanisation development processes, the density of the large cities in the countries across the continent differs, and the proportion of the population living in towns or cities with more than 100,000 inhabitants varies from country to country. From $8-34 \%$ of the population of the EU-15 member states live in cities with populations above 100,000. (In defining the population proportions we did not take the population of capital cities into account)

In terms of the number of towns or cities, Germany heads the ranking list. Germany, in fact, has 83 towns exceeding this 100,000 figure; then comes the UK with 65, Spain (55), Italy (49) and France (35). Regarding the proportion of the national population which this represents, the order is: Spain, Germany, Italy, Sweden and the Netherlands (Fig. 2).

The large city network in Eastern and Central Europe - except for Romania and Poland is thin (Fig. 3). In the whole area, 97 towns or cities are above 100,000 in population terms, and two-thirds of these are found in Poland and Romania. Slovakia has, apart from the capital, a total of one major city. In these two countries the number of regions is much lower than the number of cities but the largest of the latter are evenly distributed over the whole area and can be become potential regional centres. For this reason,

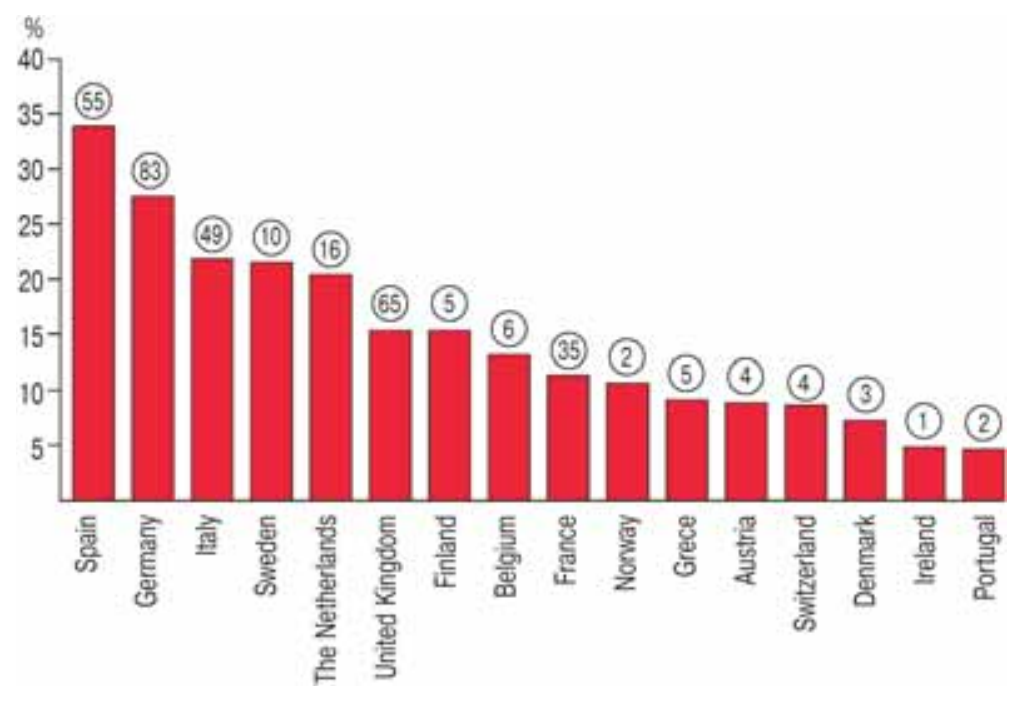

Fig. 2. Number of towns or cities with over 100,000 inhabitants in selected European countries, (excluding the capital) and their proportion of the national population, 2009.

Source: Author's own construction based on data from national statistical yearbooks 


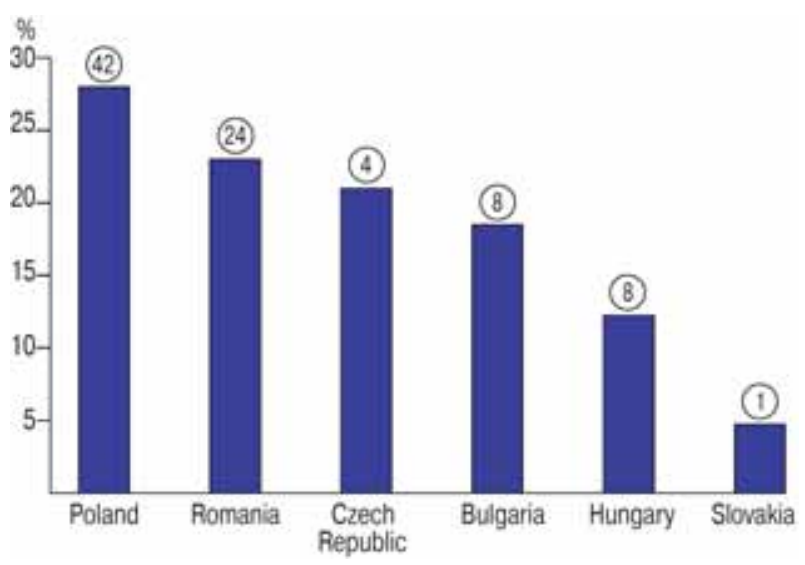

\section{Fig. 3. Number of towns or cities with over 100,000 inhabitants in Eastern and Central European countries (excluding the capital) and their proportion of national population, 2009.}

Source: Author's own construction based on data from national statistical yearbooks

therefore, designating a regional centre could be much more convenient.

In most of the Eastern and Central European countries the debates over the designation of regional centres became more intensive as the EU accession process progressed. In Poland, after the introduction of the new voivodship public administration, the leading major cities became the centres of the new regions. The only exception is the Kujawsko-Pomorske voivodship where the regional centre is not Bydgoszcz, the industrial centre with 368,000 inhabitants, but Torun, with its historical traditions and a population of 208,000. In the other countries the competition among towns or cities goes on almost exclusively in respect of the setting-up of the labour organisations of the development agencies and of changing the number of the NUTS 2 regions. The latter is especially at the centre of debate in Romania. Several cities with traditionally strong regional organising functions in the country, such as Arad, Oradea, Sibiu, and Târgu-Mures lost their potential regional centre role. These demand a change of the national regional system. The dissatisfaction in the counties belonging to the planningstatistical regions is shown by the fact that the headquarters of the regional development councils in several cases in Romania were set up in smaller county centres. There were also examples of neglect of the role of the leading cities in Bulgaria. As a result of the public administration reform undertaken in the '70s, in which, instead of small spatial units, six large "oblasts" were created, the leading major city was replaced, and a smaller-sized town in the geographical centre of the region became the regional centre.

\section{IS EASTERN AND CENTRAL EUROPE UNITARY OR DECENTRALISED?}

Should it be thought desirable to give an important future role to the meso-level units in regional policy in Eastern and Central Europe, this would clearly bring the current meso-level system into sharp focus. Both the size and economic potential of the counties in their current form are too small for them to become the basic units of decentralised regional policy, and it is to be expected that, in the future, regionalism will become stronger in more and more countries, and that this will lend weight to the re-defining of the distribution of labour between centre and provinces. There will be a serious opportunity to establish inter-regional cooperation operating on the basis of economic conformity and to increase cohesion in Eastern and Central Europe - but, even then, only if the tasks 
Table 3. The weight of capital cities in Eastern and Central Europe

(2009, as percentage of national total)

\begin{tabular}{|c|c|c|c|c|c|c|}
\hline Areas & Sofia ${ }^{2007}$ & Prague & Budapest & Warsaw & Bratislava & Bucharest ${ }^{2007}$ \\
\hline GDP & 24,6 & 24,5 & 37,4 & n.a. & 24,2 & 16,5 \\
\hline Industrial output & 15,9 & 13,0 & 17,6 & 11,8 & 37,3 & 17,0 \\
\hline $\begin{array}{l}\text { Foreign capital in- } \\
\text { vestment }\end{array}$ & 49,9 & 25,7 & 56,5 & 33,0 & 71,2 & 46,7 \\
\hline $\begin{array}{l}\text { University student } \\
\text { numbers }\end{array}$ & 43,3 & 31.4 & 49,2 & 16,7 & 83,0 & 32,4 \\
\hline R\&D employees & 72,7 & 48,0 & 55,8 & 30,0 & 40,2 & 39,0 \\
\hline
\end{tabular}

Source: Author's own construction based on national statistical yearbooks.

now accumulating (a genuine regional decentralisation of power and the creation of a regional development strategy conforming to the market economy) could be carried out, would it be possible that regionalism in its West European meaning could take root in this area. Today the driving forces of growth are concentrated in the core areas of individual countries, something which indicates, over the long term, the maintenance of the differences between the national regional units - or even their increase (Table 3).

The changes occurring during the last decade indicate that the political scope of activity within regional policy at the beginning of the new century - over and above the selfdetermination of economic development are defined by two major factors: the first of these is the EU's organisational, operational and financial reform together with Eastern enlargement, whilst the second (to no small extent influenced by the first) is the establishment of a new distribution of labour within government in the nation states - in other words, decentralisation.

Decentralisation - as proved most clearly by the processes of previous decades is now regarded in Europe as a perfectly normal phenomenon. In 1950 a quarter of the population of the continent lived in federalised or regionalised states, a figure which, by the mid-90s had risen to $60 \%$. By the end of the first decade of the following century - without taking into account the successor states of the former Soviet Union more than three-quarters of the population of Europe will live in countries where influencing the factors of economic growth, it will not be the state but rather, the subnational level which will play the defining role. This quantitative change - according to our current knowledge - will be the result of the creation of new regional administration in two countries with a high population the United Kingdom and Poland.

The basic interest of the nation-state in the future will be to try to use its power to determine economic policy within its borders to counter-balance the effects of external pressure from globalisation and integration - by increasing the ability of the regions to defend their interests in a regulated fashion. It is already the case that the traditional regional development practice of Keynesian economic policy cannot be used successfully in the new paradigm, and the state's regional policy will be substituted by the region's own policy. This paradigm change, however, cannot occur automatically, the interests of the regions being developed to different levels. In the institutionalisation of regionalism important differences are to be seen. The poorest regions can hope for improvement through outside (national and international) help, as in the past, their motivations depending more on traditional support systems than on what might be gained through the autonomy (in its wider 
sense) of a "Europe of the Regions". The devoted fans of regional decentralisation come from the group of developed regions which will clearly be the beneficiaries of the Single Market and of the Economic and Monetary Union. It is not by chance that, today, Europe's most efficient regional cooperation network (not even connected territorially) comprises: Baden-Württemberg, Lombardy, Rhône-Alpes, and Catalonia, who created a co-operation under the name "Europe's Four Engines" [Amin, Tomaney, 1995].

The general spread of regionalism, however, still faces large barriers, and national governments will continue in the future to play an important role in the connections between the regions and the EU Commission. The poorest regions of Europe can realise their interests least of all in the integration decisions, as the poor countries anyway havefewer representatives in the EU bodies. The competition policy of the EU also reinforces the effects of centralisation, and community regional policy is less capable of counterbalancing the differences emanating from varying competitive abilities. Federal Germany is the best example of this; the regional regionalism and the decrease of spatial differences can also be matched at central government level.

In parallel with the irreversible deepening of European integration, the key positions of the national government are still retained, at least in three areas. One of the most important tasks of the state is to regulate capitalism in public companies, and industrial development, even in the future, cannot be imagined without effective national financial systems, as the safest starting point for corporate strategies will be the domestic market and the regulation environment also. The other important central government task remains the coordination of national innovation and technical development programmes. Finally, as the third national level priority can be considered to be the labour market and industry-political tasks, success in fulfilling these two latter national functions, however, depends on how effective a part can sub-national public administration play in fulfilling numerous partial tasks. Consequently, regionalisation is at the same time a prerequisite for the successful operation of the nation-state, since macropolitical aims cannot be fulfilled without thoughtful human resources, educational training and enterprise development; nor can well-balanced market competition be imagined without the cooperation of the social partners. The solution of these, however, is the most optimal at the level of the regions [Keating, Loughlin, 1997].

In Eastern and Central Europe today the future of the division of power between state and region still seems uncertain. The prospects for decentralisation depend on the success of economic efficiency and the results of the "top-to-bottom" managed change of regime, but the pre-conditions at regional level for setting up power are unfavourable. In the former planned economies, the organisational framework deriving from strong centralisation has remained, even if the substance of central power has changed a great deal. Even in the most favourable cases, the process of decentralisation can be expected to be a long one.

Three possible ways of decentralisation can be envisaged in Eastern and Central Europe, and each of these differs from the others in terms of the extent and quality of the division of power. The choice of way, naturally not an arbitrary one, the historical traditions of an individual country, the nature of the economic transformation, the establishment of institutions of the market economy, political power relations and the degree of sophistication of the spatial structure all influence the decline of power concentration. The pressure to decentralise which falls on the central state administration is obviously stronger in those countries where the dynamic, regional major urban centres (for example, in Poland) wish to initiate their autonomous 
development, their structuring into the European regional division of labour, with the help of the (possibly, most liberalised) utilisation of their internal resources and post-industrial development factors. On the other hand, the legitimisation of bottomup initiatives meets greater resistance in those countries (for example, in Hungary) where the central regions have a dominant, even a strengthening, position in the factors of production increasing competitiveness. Although the example of these two countries is a good one in demonstrating that the existence of regional centres capable of being made effective is no more than a potential advantage, the "suction effect" towards decentralisation originating from the political legitimacy of Hungarian regional local authorities and the legal regulation of regional development can somehow counterbalance the lack of strong regional centres of appropriate European size.

In the first possible decentralisation model, the division of labour between central and regional bodies is organised under clear, precise rules, and the development tasks for which the two types of body are responsible differ simply in respect of which regional unit these tasks affect. To solve these problems, regional authorities even have their own income resources and have wide-ranging rights in respect of planning, and the developments of local authorities which are part of their own circle can be subsidised from these (regional) funds. Depending on the economic development level of the region, "own" and "shared" income can be supplemented by transfers from central government funds. This strategy provides the most comprehensive form of decentralisation, and, in the long-term, this is the most effective solution. However, to create this, numerous - political, constitutional, public administrational and economic - preconditions are necessary, and, even today, the progress of regional self-government in Eastern and Central Europe does not seem a realistic prospect. Further differentiation in the region will also derive from the fact that Poland and, hopefully, Hungary will take steps along the road to regionalism.

The gist of the second decentralisation strategy model is that only certain functions (planning, development, executive, authorisation and financing) are transferred from the centre to the regions, with the remaining regional, political tasks continuing within the competency of the central government. The expansion of the redistribution of power depends on the tasks which are to be decentralized, the institutional system which is to take them over and the tools which will be at the disposal of the regions. This version is the best in the short-term for those countries with a unitary system, since the preparations for transferring power need less effort, since there is no need for a complete transformation of the public administration system, since the actual influence of the central bodies does not change (which is the most important consideration), and, as the management of regional development through de-concentrated state organisation will be more complex, perhaps their efficiency will increase.

In the third option, the new division of responsibility between central and regional organs is based upon their handling of specific, occasional tasks. They create a common managing body for developing the peripheral, lagging regions, and the state provides part of its financial resources to this decision-making forum, whilst the execution of the development programmes is delegated to the spatial units. This version represents the weakest version of decentralisation, but, since there is no need to change the established power structure, it is not surprising that most Eastern and Central European countries have started to elaborate their spatial development programmes on this basis. Central governments consider this solution as the easiest way to solve the problem: they do not need to put their hands into a hornet's nest and the vertical and horizontal power relations remain untouched. 


\section{CONCLUSIONS}

The region is considered to be a spatial unit serving the sustainable growth of the economy and the modernisation of the spatial structure, with independent financial resources, fulfilling autonomous development policy and equipped with local government rights. On the basis of this term - whose factors naturally developed differently in the different periods of European development - regions have not so far existed in Eastern and Central Europe, despite the fact that some geographers (on the basis of the indisputable results obtained by geographic science in regional research) assert that we do possess some welldefined, natural regions. Such "form without content"15 - as in previous decades 15 cannot, in itself, steer the spatial structure of the country in a favourable direction, decentralise the new space-forming forces and create the pre-requisites for multipolar development. The region, if defined as a framework for regional research, is not capable of organising the space-forming powers of the $21^{\text {st }}$ century without the competencies, institutions and tools.

Regions in the new member-states are necessary, since European regional development clearly proves that a subnational level comprising approximately 1-2 million inhabitants regulated on the basis of self-government concepts (as a result of the region's economic capacity and structural abilities) is considered to be:

- the optimal spatial framework for the realisation of regional development policy, oriented towards economic development,

- the appropriate field for the operation of post-industrial spatial organisation forces, and the development of their interrelationships,

- the important area in which to enforce regional and social interests,

- the most appropriate size of spatial unit to build a modern infra-structure and the professional organisingplanning-executing institution of regional policy,

- the main factor in the decision-making system of the European Union's Regional and Cohesion policy.

\section{REFERENCES}

1. Amin, A., Tomaney, J. (1995) The regional dilemma in a neo-liberal Europe. European Urban and Regional Studies. 2. P. 171-188.

2. Bachtler, J., Downes, R., Gorzelak, G. (Eds.) (2000) Transition, Cohesion and Regional Policy in Central and Eastern Europe. Aldershot, Ashgate.

3. Blažek, J., Boeckhout, S. (2000) Regional policy in the Czech Republic and EU accession. In: Bachtler, J., Downes, R., Gorzelak, G. (Eds.) Transition, Cohesion and Regional Policy in Central and Eastern Europe. Aldershot, Ashgate. P. 301-318.

4. Boev, J. (2002) Bulgaria: decentralization and modernization of public administration. In: Péteri, G. (Ed.): Mastering Decentralization and Public Administration Reforms in Central and Eastern Europe. Budapest, Open Society Institute, Local Government and Public Service Reform Initiative. P. 93-120. 
5. Cities in the new EU countries. Position, problems, policies. Amsterdam, Ministry of the Interrior and Kingdom Affairs. 2004.

6. Enyedi, Gy., Tózsa, I. (Eds.) (2004) Region. Regional Development Policy, Administration and E-government. Budapest, Akadémiai Kiadó.

7. Gál, Z. (Ed.) (2001) Role of the Regions in the Enlarging European Union. Pécs, Centre for Regional Studies, HAS. Discussion Papers, Special Issue.

8. Geshev, G. (Ed.) (1997) The Geographical Space - an Investment for the $21^{\text {th }}$ Century. Sofia, Institute of Geography, BAS.

9. Geshev, G. (2001) The role of the regions of South-Eastern space in the enlarging European Union. In: Gál, Z. (Ed.): Role of the Regions in the Enlarging European Union. Pécs, Centre for Regional Studies, HAS. Discussion Papers, Special Issue. P. 81-100.

10. Gorzelak, G. (1998) Regional and Local Potential for Transformation in Poland. Warsaw, University of Warsaw.

11. Horváth, Gy. (1996) Transition and regionalism in East-Central Europe. Tübingen, Europäischen Zentrum für Föderalismus-Forschung. Occasional Papers, 7.

12. Horváth, Gy. (2010) Regionalism in a unitary state: the case of Hungary. In: Scully, R., Wyn Jones, R. (Eds.): Europe, Regions and European Regionalism. Basingstoke, Palgrave Macmillan. P. 184-202.

13. Illner, M. (2000) Issues of decentralization. Reforms in former communist countries. Infomationen zur Raumforschung. 7-8. P. 391-401.

14. Keating, M., Hughes, J. (Eds) (20003) The Regional Challenge in Central and Eastern Europe. Territorial Restructuring and European Integration. Brussels, Presses interuniversitaires européennes/Peter Lang.

15. Keating, M., Loughlin, J. (Eds.) (1997) The Political Economy of Regionalism. London, Frank Cass.

16. Lütgenau, S. A. (Ed.) (2011) Regionalization and Minority Problems in Central Europe. Case Studies from Poland, Slovakia, Hungary and Romania. Innsbruck, Studien Verlag.

17. Michalski, A., Saraceno, A. (2000) Regions in Enlarged European Union. Brussels, EC, Forward Studies Unit.

18. Potentials for polycentric development in Europe. Annex Report B. Stockholm, Nordic Centre for Spatial Development. August 2004.

19. Schindegger, F., Tatzberger, G. (2002) Polizentrismus - ein europisches Leitbild für die räumliche Entwicklung. Wien, ÖROK.

20. Stasiak, A. (1999) The new administrative division of Poland. In: Duró, A. (Ed.): Spatial Research in Support of the European Integration. Pécs, Centre for Regional Studies HAS. P. 31-42. 
21. Waterhout, B. (2002) Polycentric Development: What is behind it? In: Faludi, A. (Ed.): European Spatial Planning. Cambridge (MA), Lincoln Institute of Land Policy. P. 83-103.

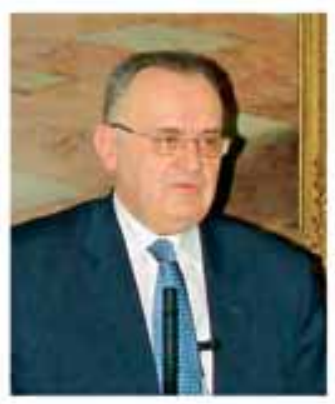

Gyula Horváth is Professor in Regional Economics and Policy of the University of Pécs and Director of the Centre for Regional Studies, Hungarian Academy of Sciences. He is member of the Academia Europaea (London) and president of the Hungarian Regional Science Association. His specialized professional competence is European regional policy, restructuring and regional transformation in Eastern and Central Europe. He is author, editor and co-editor of 30 books and over 300 articles/ papers (in Hungarian and in foreign languages). He has undertaken extensive advisory and consultancy work within Hungary and Europe. He is member of the Evaluation Board of the Framework Programme of the European Commission and external expert in RIS, RITTS, PHARE, and TACIS projects of the European Commission. 